International Journal of Environmental, Sustainability, and Social Sciences

ISSN 2720-9644 (print); ISSN 2721-0871 (online)

https://journalkeberlanjutan.com/index.php/ijesss

Volume: 2

Number: 2

Page: $71-78$

\title{
PHILOSOPHY OF TRI KAYA PARISUDHA TOWARDS AUDITOR PRESSURE PHENOMENON OF PROCEDURE STOPPING
}

\author{
${ }^{1}$ Ni Putu Riski MARTINI, ${ }^{2}$ Ketut Puja Wirya SANJAYA \\ 1,2Faculty of Economics and Business, University of Warmadewa, \\ Indonesia \\ Corresponding author: Ni Putu Riski MARTINI \\ Faculty of Economics and Business, University of Warmadewa \\ Indonesia \\ Email: riskimartini@gmail.com
}

Article History:
Received: 2021-06-30
Revised: 2021-07-15
Accepted: 2021-07-28

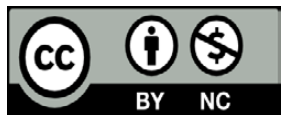

\begin{abstract}
:
This study discusses the factors that are thought to have an effect on premature termination of audit procedures, which can be caused by external factors related to situational factors during the audit process that will affect the behavior of auditors in conducting audits. In addition, the auditors' awareness and sensitivity in preventing or detecting fraud is influenced by the application of Tri Kaya Parisudha cultural concept. This research was conducted at a public accounting firm in Bali. The population of this research is 16 public accounting firms in Bali with 122 auditors. The sampling technique used in this research is purposive sampling technique. Based on the results of the analysis, it can be concluded that: time pressure and compliance pressure have a positive effect on premature audit procedures and the Tri Hita Karana philosophy is able to moderate the relationship between time pressure and adherence pressure on premature audit procedures.
\end{abstract}

\section{Keywords:}

Tri Kaya Parisudha, Audit Premature Termination, Time Pressure, Obedience Pressure

Cite this as: MARTINI, N.P.R, SANJAYA, I.K.P.W, (2021). "The Philosophy Of Tri Kaya Parisudha Towards Auditor Pressure Phenomenon Of Audit Procedure Stopping“. International Journal of Environmental, Sustainability, and Social Sciences 2 (2), 71-78, https://doi.org/10.38142/ijesss.v2i2.74

\section{INTRODUCTION}

An audit of financial statements by an independent auditor in general is to express an opinion on the fairness of the company's audited financial statements. Although in theory it is clearly stated that a good audit is one that can improve the quality of information, the reality on the ground shows something different. The Enron case is one proof of the failure of Arthur Andersen in conducting an audit. Arthur Andersen from 1985 to 2000 always gave an unconditional fair opinion, but surprisingly Enron went bankrupt on December 2, 2001. In that case, the auditors were deemed to have played a part in providing false information, so that many parties suffered substantial material losses (Barrainkua \& Espinosa-Pike, 2018; Izzalqurny et al., 2019). These cases of audit irregularities indicate a decrease in audit quality, which is caused by a dysfunctional audit behavior. Mohd-Sanusi et al., (2015) states that there are three deviant audit behaviors, namely: 1) Under reporting of audit time, namely the act of reporting the audit time with a total time that is shorter than the actual time, 2) Replacing and alerting original audit procedures, namely changing actions. procedures that have been determined in the implementation of audits in the field, 3) Premature 
sign off of audit steps without completion of the procedure, namely the action of completing audit steps too early, without completing the entire procedure. Public Oversight Board states that $85 \%$ of the forms of irregularities that occur in the audit process are deviations in the completion of steps audits too early and without completing the entire procedure. $12.2 \%$ of the forms of deviations that occur are reporting the audit time that is shorter than the actual time, and the remaining deviations occur due to lack of audit evidence and changes in audit procedures that have been determined during field inspections (Muslim, 2020; Reverte, 2009).

Deviations in completing audit steps that are too early represent a reduction in quality by the auditor, through actions such as reducing the number of audit samples, conducting in-depth reviews of client documents, not expanding examinations when items are unclear, or auditors providing audit opinions. when all required audit procedures have not been completed. Yang et al., (2018) detects the reasons why auditors perform premature termination of audit procedures, namely the limited audit timeframe specified, the assumption that the audit procedures performed are not important (low risk), the audit procedures are immaterial, the audit procedures are poorly understood. There is a time limit for submitting the audit report, as well as the influence of the auditor's boredom factor. Behavioral deviations in auditing can be caused by personal characteristics of auditors and situational factors when conducting an audit (Ajzen, 2015). This study aims to examine the factors that are thought to have an effect on premature termination of audit procedures, which could be caused by external factors related to situational factors during the audit process that will affect the auditor's behavior in carrying out the audit. In this study, the factors that will be studied are the factors that cause auditors to feel pressure in carrying out certain audit tasks, which in turn can affect the behavior of auditors in implementing the audit process (Allegrini \& D'Onza, 2003). This is in accordance with the theoretical model of work stress, which states that the stressor (causes of stress) faced by individuals in the work environment can cause individuals to feel pressure (stress) in doing work, and in turn can affect individual attitudes, intentions and behavior. The factors that will be examined in this research are time pressure and obedience pressure (Power, 2003). A tight time budget can result in an imbalance between the available audit time budget and the time needed to complete the audit program, this is one of the triggers for pressure faced by auditors. Another factor that causes pressure to be experienced by auditors is the obedience pressure caused by clients or leaders, this sometimes makes auditors take actions that violate audit standards, with the consequence that auditors are no longer independent or consequently will receive sanctions in the form of termination of assignments from clients (Murphy, 2013).

The auditor's awareness and sensitivity in preventing or detecting fraud is not only done through the application of a good internal control system but also requires the application of a noble local culture, such as local wisdom inherent in individual communities and employees of these agencies. In Bali, it is known for the concept of the Tri Kaya Parisudha culture. This concept is embraced and becomes the basis of community life in Bali. Tri Kaya Parisudha is a form of local wisdom in Balinese society. Tri Kaya Parisudha has noble values that can guide people in living life in all aspects. The values contained in Tri Kaya Parisudha teach humans to think, say and do good and right. Tri Kaya Parisudha explains the three actions or behaviors that must be purified, namely thinking right / holy, saying the right thing and doing or behaving right (Sujana et al., 2019; Sujana \& Saputra, 2020; Susilawati et al., 2016; Yasa \& Prayudi, 2019). 


\section{International Journal of Environmental, Sustainability, and Social Sciences ISSN 2720-9644 (print); ISSN 2721-0871 (online) \\ https://journalkeberlanjutan.com/index.php/ijesss}

The reason behind the selection of this variable as a moderating variable is because this research was conducted on auditors in Bali. In Bali, there are various values and concepts that are used as guidelines or references in society. One of them is the Tri Kaya Parisudha concept which is the three bases of good behavior from the existence of good thoughts, good words and good deeds. If it is associated with efforts to prevent acts of irregularities or fraud, Tri Kaya Parisudha leads to the formation of values, attitudes and morals of auditors in avoiding and preventing acts of fraud from occurring in the organization. Therefore, the title of this research is, "The Philosophy of Tri Kaya Parisudha Against the Phenomenon of Auditor Pressure on Premature Termination of Audit Procedures."

This research examines the relationship between time pressure and dysfunctional audit behavior in the form of premature termination of audit procedures. The time pressure exerted by the Public Accounting Firm on its auditors aims to reduce audit costs. The faster the time for the audit, the lower the cost of conducting the audit. The existence of this time pressure forces auditors to complete tasks in accordance with a predetermined time budget. Performing audit procedures under time pressure conditions will result in different audit results, when compared to conditions without time pressure (Ghazali et al., 2014; Mohd-Sanusi et al., 2015). The relationship between time pressure and premature termination of audit procedures is positive. The greater the time pressure, the greater the tendency for premature termination of audit procedures, and vice versa. Based on the description above, the hypotheses proposed in this study are:

H1: Time pressure has a positive effect on premature termination of audit procedures.

This study examines the relationship between compliance pressure and dysfunctional audit behavior in the form of premature termination of audit procedures. Obedience pressure can be measured by the desire not to fulfill the client's desire to behave deviating from professional standards, will oppose the client for upholding professionalism and will oppose the superior if forced to do things that are contrary to professional and moral standards (Mohd-Sanusi et al., 2015; Sarwoko \& Agoes, 2014). Based on the description above, the hypotheses proposed in this study are:

H2: Compliance pressure has a positive effect on premature termination of audit procedures.

This study examines the effect of the Tri Kaya Parisudha philosophy on the relationship between time pressure and premature termination of audit procedures. Tri Kaya Parisudha is one of the philosophies of Balinese culture which teaches every human being to always do good to practice the truth, to have ethics and noble character through fostering attitudes. Kepramareni et al. (2014) found that the application of the Tri Kaya Parisudha concept encourages accountability in the management of a non-profit organization (Sujana \& Saputra, 2020). The Tri Kaya Parisudha philosophy is thought to be able to control individual behavior, so that the level of Tri Kaya Parisudha in the auditor can weaken the influence of the time pressure experienced by the auditor in carrying out his duties, so as to be able to pressure the auditor to neglect the audit procedure which should be done in the form of premature termination of the audit procedure. Auditors with a high level of Tri Kaya Parisudha in themselves will not fall for it to prematurely terminate the audit procedure even in conditions of time pressure (Atmaja \& Subawa, 2018; Sujana et al., 2019; Sujana \& Saputra, 2020; Susilawati et al., 2016). Based on the framework that has been described, the hypotheses proposed are:

H3: Tri Kaya Parisudha's philosophy weakens the effect of time pressure on premature termination of audit procedures. 
International Journal of Environmental, Sustainability, and Social Sciences

ISSN 2720-9644 (print); ISSN 2721-0871 (online)

https://journalkeberlanjutan.com/index.php/ijesss

\section{METHODS}

This research was conducted at a public accounting firm in Bali. The time of research is 2020. Population is a generalization area consisting of objects / subjects that have certain qualities and characteristics that are determined by the researcher for study and then draw conclusions. The population of this study were 16 Public Accounting Firms in Bali with 70 auditors. The sample is part of the number and characteristics of the population. The sampling technique used in this study is purposive sampling technique, namely sampling with respondents used in this study is based on the criteria that have been determined by the researcher. The data analysis technique used is Moderated Regression Analysis (MRA). Moderated Regression Analysis (MRA) is an interaction test which is a special application of linear multiple regression where the regression equation contains an element of interaction (multiplication of two or more independent variables).

\section{RESULTS AND DISCUSSION}

The number of questionnaires distributed in this study was 70 copies. Researchers did not distribute questionnaires to one on the grounds that the had closed. Of all the number of questionnaires sent, 65 were returned questionnaires and 5 did not return. The returns to the questionnaire are $92,85 \%$. The validity test is used to measure whether a questionnaire is valid or not. A questionnaire is said to be valid if the correlation between the item score and the total score is positive and is more than 0.30. The results of the variable validity test in this study were all above 0.3 so that they passed the validity test. Reliability testing in this study was carried out using the Cronbach Alpha statistical test through the SPSS program, where a variable is said to be reliable if it provides a Cronbach alpha value greater than 0.6 . The results of the instrument reliability test will be presented in Table 1 as follows:

Table 1. Reliability Test Results

\begin{tabular}{lcc}
\hline \multicolumn{1}{c}{ Research Variables } & Croncbach's Alpha & Description \\
\hline Time Pressure & 0,832 & Reliable \\
Obedience Pressure & 0,978 & Reliable \\
Premature Audit Procedure & 0,895 & Reliable \\
Philosophy Tri Kaya Parisudha & 0,905 & Reliable \\
\hline
\end{tabular}

Source: Data processed 2021

Based on the table, it can be seen that all research instruments are declared reliable because each variable has a Cronbach's alpha value above 0.60 . The normality test is a test that aims to test whether in the regression model the confounding or residual variables have a normal distribution. The method that can be used to see the residual normality is the Kolmogorov-Smirnov (K-S) non-parametric statistical test with the help of the SPSS program. Data are normally distributed or cannot be seen from the Asymp value. Sig. (2-tailed). If the value is Asymp. Sig. (2-tailed is greater than $0.05(a=5 \%)$, then the data is normally distributed. The results of the normality test will be presented in the following table 2 .

Table2. Residual Normality Test Results

\begin{tabular}{ccc}
\hline Bound Variable & Kolmogorov-Smirnov Z & Asymp. Sig \\
\hline Premature Audit Procedure & 1,526 & 0,183 \\
\hline
\end{tabular}


International Journal of Environmental, Sustainability, and Social Sciences

ISSN 2720-9644 (print); ISSN 2721-0871 (online)

https://journalkeberlanjutan.com/index.php/ijesss

Source: Data processed 2021

It can be seen that the Asymp. Sig. (2-tailed) 0.183 is greater than the value of $a=$ 0.05 , it can be concluded that the data is normally distributed.

Table 3. Heteroscedasticity Test Results

\begin{tabular}{lcc}
\hline \multicolumn{1}{c}{ Research Variables } & Performance & Sig. \\
\hline Time Pressure & 1,411 & 0,068 \\
Obedience Pressure & 1,632 & 0,078 \\
Premature Audit Procedures & 1,523 & 0,091 \\
The philosophy of Tri Kaya Parisudha & 1,302 & 0,114 \\
\hline
\end{tabular}

Source: Data processed 2021

Based on the table shows that none of the independent variables have a significant effect on the dependent variable, it can be concluded that the regression model is free from heteroscedasticity symptoms. Moderated Regression Analysis (MRA) is an interaction test which is a special application of linear multiple regression where the regression equation contains an element of interaction (multiplication of two or more independent variables). The independent variables in this study are competence and TABK and the dependent variable is audit quality. The moderated regression equation model on the F-test with the Anova test, a significance level of 0.000 was obtained which is smaller than $a=0.05$. The significance level value indicates that the time pressure and compliance pressure variables have a significant effect on premature audit procedures. Adjusted R Square from the independent variable to the dependent variable is 0.785 or 78.5 percent. This means that 78.5 percent of the variation in audit quality is influenced by variations in time pressure and compliance pressure, while the remaining 21.5 percent is influenced by variations in other factors that are not included in the regression equation model. Many researchers recommend using the Adjusted R Square value when evaluating the best regression model. This is due to the weakness of the coefficient of determination ( $R$ Square) which is biased towards the number of independent variables that are included in the model. Every additional one independent variable, $\mathrm{R}$ Square must increase regardless of whether the variable influences or does not significantly on the dependent variable, while the Adjusted $\mathrm{R}$ Square value can increase or decrease if one independent variable is added to the model.

Hypothesis testing can be seen from the results of the t test in Table 5.9 using the help of the SPSS version 17.0 program. The steps used in this test are as follows: The coefficient results show that the time pressure value is positive 2.725 , the t-test value is 5.330 and the significance level is 0.000 . The significance level is smaller than the specified alpha level $(a=0.05)$, this means that time pressure has a positive effect on premature termination of the audit. So that the first hypothesis in this study can be accepted. The coefficient results show that the value of obedience pressure is positive 1.459 , the t-test value is 8.133 and the significance level is 0.001 . The significance level is smaller than the specified alpha level $(a=0.05)$, this means that compliance technology has a positive effect on premature audit termination. So that the second hypothesis in this study can be accepted. The regression coefficient on the Tri Kaya Parisudha philosophy moderates the effect of time pressure on premature audit procedures is 0.633 with a t-test value of 3.033 and a significance of 0.000 . This means that the third hypothesis, namely the Tri Kaya Parisudha philosophy, is able to moderate the relationship between time pressure on premature audit procedures and is acceptable. The regression coefficient on the Tri Kaya Parisudha philosophy 
moderates the effect of pressure on obedience to premature audit procedures is 1.787 with a t-test value of 4.221 and a significance of 0.000 . This means that the fourth hypothesis, namely the philosophy of Tri Kaya Parisudha, is able to moderate the relationship between pressure for adherence to premature audit procedures can be accepted.

Time pressure is one of the factors that create stressors faced by auditors and can cause auditors to perform premature termination of audit procedures (Ghazali et al., 2014; Mohd-Sanusi et al., 2015). The relationship between time pressure and premature termination of audit procedures is positive. The greater the time pressure, the greater the tendency for premature termination of audit procedures. The time pressure exerted by the Public Accounting Firm on its auditors aims to reduce audit costs. The faster the time for the audit, the lower the cost of conducting the audit. The existence of this time pressure forces auditors to complete tasks in accordance with a predetermined time budget. Performing audit procedures under time pressure conditions will result in different audit results, when compared to conditions without time pressure. The relationship between time pressure and premature termination of audit procedures is positive. The greater the time pressure, the greater the tendency for premature termination of audit procedures, and vice versa (C. I. R. S. Dewi et al., 2019; Paino et al., 2015). Pressure of compliance is one of the factors that creates stressors faced by auditors and may cause auditors to perform premature termination of audit procedures. In addition, there is also an attribution theory which explains how people interpret the causes of other people's behavior, whether due to internal or external factors. Auditors often experience a dilemma in applying auditors' professional standards in their decision making (Sarwoko \& Agoes, 2014). The power of clients and leaders causes auditors to be no longer independent, because auditors become depressed in carrying out their work. Clients or leaders may pressure auditors to violate auditors' professional standards (Yee, 2009). This of course will create pressure on the auditor to comply or not comply with the wishes of the client or leader. So that sometimes this pressure can make auditors take actions that violate audit standards.

This study examines the effect of the Tri Kaya Parisudha philosophy on the relationship between time pressure and premature termination of audit procedures. Tri Kaya Parisudha is one of the philosophies of Balinese culture which teaches every human being to always do good to practice the truth, to have ethics and noble character through fostering attitudes. Sujana \& Saputra (2020) found that the application of the Tri Kaya Parisudha concept encourages accountability in the management of a non-profit organization. In addition, Susilawati et al., (2016) conducted research on the ethical behavior of auditors, and found that Tri Kaya Parisudha was able to increase the ethical sensitivity of auditors. From the results of several previous studies, it can be concluded that purification and control of thoughts (manacika), actions (kayika) and words (wacika) are very important in shaping individual ethical behavior (I. G. P. E. R. Dewi, 2018; Rosalina, 2017). In this study, the relationship between the Tri Kaya Parisudha philosophy is thought to be able to control individual behavior, so that the level of Tri Kaya Parisudha in the auditor can weaken the influence of the time pressure experienced by the auditor in carrying out his duties, so as to pressure the auditor to ignore audit procedures that should be done in the form of premature termination. audit procedures (I. G. P. E. R. Dewi, 2019; Sujana et al., 2019). Auditors with a high level of Tri Kaya Parisudha in themselves will not fall for it to prematurely terminate the audit procedure even in conditions of time pressure. Sujana et al., (2019) found that the application of the Tri Kaya Parisudha concept encourages accountability in the management of a non-profit organization. In addition, Sujana \& Saputra (2020) conducted research on the ethical behavior of auditors, and found that Tri Kaya Parisudha was able to increase the ethical sensitivity of auditors. From the results of several previous studies, it can be concluded that 
International Journal of Environmental, Sustainability, and Social Sciences

ISSN 2720-9644 (print); ISSN 2721-0871 (online)

https://journalkeberlanjutan.com/index.php/ijesss

purification and control of thoughts (manacika), actions (kayika) and words (wacika) are very important in shaping individual ethical behavior (Yousaf et al., 2016). In this study, the relationship between the Tri Kaya Parisudha philosophy is thought to be able to control individual behavior, so that the level of Tri Kaya Parisudha in the auditor can weaken the influence of the obedience pressure experienced by auditors in carrying out their duties, so as to be able to pressure auditors to ignore audit procedures that should be done in the form of premature termination. audit procedures. Auditors with a high level of Tri Kaya Parisudha in themselves, will not fall for the premature termination of audit procedures even in conditions of compliance pressure (Atmaja \& Subawa, 2018; Mohd-Sanusi et al., 2015; Sujana \& Saputra, 2020).

\section{CONCLUSION}

The conclusions in this study are: Time pressure and compliance pressure experienced by auditors have a positive effect on premature termination of audit procedures. The Tri Hita Karana philosophy is able to moderate the effects of time pressure and compliance pressure on premature termination of audit procedures. The object used by researchers is only the scope of the Province of Bali, for further researchers can research in other areas. Second, this study limits the variables that affect premature audit termination with the variables of time pressure, compliance pressure and the philosophy of Tri Hita Karana. Other researchers can use other variables to examine the factors that influence the premature audit procedure.

\section{REFERENCES}

Agoglia, C. P., Hatfield, R. C., \& Lambert, T. A. (2015). Audit team time reporting: An agency theory perspective. Accounting, Organizations and Society, 44, 1-14. https: / / doi.org/10.1016/j.aos.2015.03.005

Ajzen, I. (2015). Consumer attitudes and behavior: the theory of planned behavior applied to food consumption decisions. Rivista Di Economia Agraria, 70(2), 121-138. https: / /doi.org/10.13128/REA-18003

Allegrini, M., \& D’Onza, G. (2003). Internal Auditing and Risk Assessment in Large Italian Companies: an Empirical Survey. International Journal of Auditing, 7(3), 191208. https: //doi.org/10.1046/j.1099-1123.2003.00070.x

Atmadja, A. T., Saputra, K. A. K., \& Manurung, D. T. H. (2019). Proactive Fraud Audit , Whistleblowing and Cultural Implementation of Tri Hita Karana for Fraud Prevention. European Research Studies Journal, XXII(3), 201-214.

Atmaja, I. K. M., \& Subawa, N. S. (2018). Human Resource Development Model Based on Local Wisdom Tri Kaya Parisudha in Dealing with Globalization. Journal of Management and Business, 15(3), 100-117.

Barrainkua, I., \& Espinosa-Pike, M. (2018). The influence of auditors' professionalism on ethical judgement: Differences among practitioners and postgraduate students. Revista de Contabilidad-Spanish Accounting Review, 21(2), 176-187. https: / / doi.org/10.1016/j.rcsar.2017.07.001

Damayanti, N. N. S. R. (2019). The Effect of Work Engagement and Self-Efficacy on Job Burnout of Credit Analyst. International Journal of Applied Business and International Management, 4(3), 113-120. https://doi.org/10.32535/ijabim.v4i3.689

Dewi, C. I. R. S., Surya, L. P. L. S., \& Saputra, K. A. K. (2019). The Effect of Managerial Ownership and Institutional Ownership on the Selection of Public Accounting Firms in Mining Companies Listed on the Indonesia Stock Exchange. Dialectics: Journal of Economics and Social Sciences, 4(1), 26-33. https://doi.org/10.36636/dialektika.v4i1.283

Dewi, I. G. P. E. R. (2018). Philosophy Tri Kaya Parisudha As Moderators The Effect Of 


\section{International Journal of Environmental, Sustainability, and Social Sciences \\ ISSN 2720-9644 (print); ISSN 2721-0871 (online) \\ https://journalkeberlanjutan.com/index.php/ijesss}

Equity Sensitivity And Ethical Sensitivity On Auditor Ethical Behavior In Financial Audit Board Of Republic Indonesia (BPK RI) Representatives Of Bali Province. International Journal of Research Publications, 10(1).

Dewi, I. G. P. E. R. (2019). Tri Kaya Parisudha's Philosophy Moderates the Effect of Equity Sensitivity and Ethical Sensitivity on the Ethical Behavior of the Auditors of the State Audit Board of Bali Province. IHDN Journal of Quality Assurance, 5(1), 4356.

El-menouar, Y. (2014). The Five Dimensions of Muslim Religiosity . Results of an Empirical Study. Methods, Data, Analyses, 8(1), 53-78. https: / / doi.org/10.12758/mda.2014.003

Erhemjamts, O., \& Huang, K. (2019). Institutional ownership horizon, corporate social responsibility and shareholder value. Journal of Business Research, 105(January 2018), 61-79. https://doi.org/10.1016/j.jbusres.2019.05.037

Ghazali, M. Z., Rahim, M. S., Ali, A., \& Abidin, S. (2014). A Preliminary Study on Fraud Prevention and Detection at the State and Local Government Entities in Malaysia. Procedia - Social and Behavioral Sciences, 164(August), 437-444. https://doi.org/10.1016/j.sbspro.2014.11.100

Izzalqurny, T. R., Subroto, B., \& Ghofar, A. (2019). Research in Business and Social Science Relationship between Financial Ratio and Financial Statement Fraud Risk Moderated by. International Journal of Research in Business and Social Science, 8(4), 34-43.

Mohd-Sanusi, Z., Khalid, N. H., \& Mahir, A. (2015). An Evaluation of Clients' Fraud Reasoning Motives in Assessing Fraud Risks: From the Perspective of External and Internal Auditors. Procedia Economics and Finance, 31(15), 2-12. https: / doi.org/10.1016/s2212-5671(15)01126-0

Murphy, C. (2013). Fraud Prevention and Detection in the Public Sector (Issue June).

Muslim, H. M. S. (2020). Moderating Ethics Auditors Influence of Competence, Accountability on Audit Quality. Jurnal Akuntansi, 23(3), 468. https://doi.org/10.24912/ja.v23i3.614

Mustikawati, F., Puspitasari, D., Murtini, H., \& Gunawan, D. I. (2017). Perception of Village Financial Managers of Accounting Fraud Tendency ( Empirical Study in Grobogan District).

Paino, H., Razali, F. M., \& Jabar, F. A. (2015). The Influence of External Auditor's Working Style, Communication Barriers and Enterprise Risk Management toward Reliance on Internal Auditor's Work. Procedia Economics and Finance, 28(April), 151-155. https://doi.org/10.1016/s2212-5671(15)01094-1

Power, M. K. (2003). Auditing and the production of legitimacy. Accounting, Organizations and Society, 28(4), 379-394. https://doi.org/10.1016/S03613682(01)00047-2

Reverte, C. (2009). Determinants of corporate social responsibility disclosure ratings by Spanish listed firms. Journal of Business Ethics, 88(2), 351-366. https: / / doi.org/10.1007/s10551-008-9968-9

Rosalina, P. D. (2017). The Implementation Of Hindu Philosophy "Tri Kaya Parisudha" For Sustainable Tourism In Munduk Village, North Bali. JUMPA, 3(2), 223-237.

Saputra, K. A. K. (2020). The Performance Of The Internal Auditors Of The Village Rural Institution. International Journal of Environmental, Sustainability, and Social Sciences, 1(2), 28-35.

Sarwoko, I., \& Agoes, S. (2014). An Empirical Analysis of Auditor's Industry Specialization, Auditor's Independence and Audit Procedures on Audit Quality: Evidence from Indonesia. Procedia - Social and Behavioral Sciences, 164(August), 271-281. https://doi.org/10.1016/j.sbspro.2014.11.077

Singh, V. L., \& Singh, M. (2018). A burnout model of job crafting: Multiple mediator effects on job performance. IIMB Management Review, 30(4), 305-315. 
International Journal of Environmental, Sustainability, and Social Sciences

ISSN 2720-9644 (print); ISSN 2721-0871 (online)

https://journalkeberlanjutan.com/index.php/ijesss

https: / / doi.org/10.1016/j.iimb.2018.05.001

Sujana, E., \& Saputra, K. A. K. (2020). Fraud Detection and Prevention Methods: Inspector' $\mathrm{s}$ Auditor' $\mathrm{s}$ Perception in Bali. Journal of Advance Research in Dynamical and Control System, 8-16. https: / / doi.org/10.5373/JARDCS/V12I4/20201413

Sujana, E., Yasa, I. N. P., \& Wahyuni, M. A. (2019). Testing of Fraud Diamond Theory Based on Local Wisdom on Fraud Behavior. Advances in Economics, Business and Management Research, 69(3), 12-15.

Susilawati, M., Ludigdo, U., Irianto, G., \& Baridwan, Z. (2016). Frame Value of Strategic Management Accounting Based on The Balance of Tri Kaya Parisudha. Accounting and Finance Review, 1(1), 66-75.

Verma, V. K., \& Chandra, B. (2018). An application of theory of planned behavior to predict young Indian consumers' green hotel visit intention. Journal of Cleaner Production, 172(3), 1152-1162. https://doi.org/10.1016/j.jclepro.2017.10.047

Wong, O. W. B., \& Lui, M. C. G. (2007). Culture, implicit theories and the attribution of morality. Behavioral Research in Accounting, 19(1), 231-246. https: / / doi.org/ 10.2308/bria.2007.19.1.231

Yan, H., \& Xie, S. (2016). How does auditors' work stress affect audit quality? Empirical evidence from the Chinese stock market. China Journal of Accounting Research, 9(4), 305-319. https://doi.org/10.1016/j.cjar.2016.09.001

Yang, S., Liu, Y., \& Mai, Q. (2018). Is the quality of female auditors really better? Evidence based on the Chinese A-share market. China Journal of Accounting Research, 11(4), 325-350. https://doi.org/10.1016/j.cjar.2018.07.004

Yasa, I. N. P., \& Prayudi, M. A. (2019). Ethical values based on local wisdom and tax compliance behavior. Journal of Economics and Business, 22(2), 361-390. https: / /doi.org/ 10.24914/jeb.v22i2.2527

Yee, H. (2009). The re-emergence of the public accounting profession in China: A hegemonic analysis. Critical Perspectives on Accounting, 20(1), 71-92. https://doi.org/10.1016/j.cpa.2007.03.008

Yousaf, M., Ihsan, F., \& Ellahi, A. (2016). Exploring the impact of good governance on citizens' trust in Pakistan. Government Information Quarterly, 33(1), 200-209. https://doi.org/10.1016/j.giq.2015.06.001 